\title{
The Influence Analysis of Social Media Marketing Activities' Dimensions on Customer Loyalty through Value Equity, Brand Equity, and Relationship Equity to Shopee Indonesia Customers in Surabaya
}

\author{
Zatira Yuningwati Sutrisno ${ }^{\mathrm{a}}$, Ronald Suryaputra ${ }^{\mathrm{b}}$, Amelia $^{\mathrm{c} *}$ \\ a zatirastrsn@gmail.com \\ ${ }^{a}$ Master of Management Student at Pelita Harapan University, Surabaya 60234, Indonesia \\ ${ }^{b, c}$ The Lecturer of Master of Management at Pelita Harapan University, Surabaya 60234, Indonesia
}

\begin{abstract}
Shopee can prove itself as a big successful e-commerce company. This can be seen after one year of operation since 2015, Shopee has succeeded in serving transactions worth US \$ 1.8 billion (Rp.24 trillion) with a growth of around 43\% per month. The main objective of this research is to examine Shopee Indonesia's customer loyalty in Surabaya. All variables that may affect Shopee Indonesia's customer equity driver can also be identified in this study. This study aims to determine how the influence of Social Media Marketing Activities (SMMA) with dimensions of Interactivity, Informativeness, Word of Mouth, Personalization, and Trendiness on Customer Loyalty through Value Equity, Brand Equity, and Relationship Equity. The expected benefit of this research is to increase the repertoire of knowledge in the field of management, especially how much influence Social Media Marketing Activities, Value Equity, Brand Equity, and Relationship Equity will increase sustainable transactions from Shopee Indonesia's social media (Instagram) customers in Surabaya. This research is a causal study with quantitative method by processing data using AMOS. Data collection was carried out by distributing questionnaires to 135 respondents with characteristics of male and female respondents aged 1860 years, domiciled in Surabaya, have shopped at Shopee at least twice in the last three months, and have shopped at other e-commerce sites in the last two months. The results showed that Interactivity significantly affected SMMA; Informativeness significantly affected SMMA; Word of Mouth significantly affected SMMA; Personalization significantly affected SMMA; Trendiness significantly affected SMMA; SMMA significantly affected Value Equity; SMMA insignificantly affected Brand Equity; SMMA significantly affected Relationship Equity; Value Equity significantly affected Customer Loyalty; Brand Equity insignificantly affected Customer Loyalty; and Relationship Equity insignificantly affected Customer Loyalty.
\end{abstract}

Keywords: Interactivity, Informativeness, Word of Mouth, Personalization, Trendiness, Social Media Marketing Activities, Value Equity, Brand Equity, Relationship Equity, Customer Loyalty.

\section{Main text}

E-commerce can be interpreted as any process of buying and selling goods and services online, where since 2014, the history of e-commerce in Indonesia has continued jump. This is marked by the large injections of funds from investors received by various e-commerce sites. In 2016, the government released the Indonesian E-commerce Roadmap for 2017 to 2019, which was outlined in the form of Presidential Decree Number 74 of 2017 concerning the E-Commerce Road Map for 2017-2019, and also referred to as another term for the Electronic-Based National Trade System Roadmap (SPNBE) 2017-2019. The 2017-2019 SPNBE contains 
eight aspects, namely on Funding, Taxation, Consumer Protection, Education and Human Resources, Logistics, Communication Infrastructure, Cyber Security, and Establishment of Executive Management (https://www.kompasiana.com/www.bhinneka.com/, downloaded on 18th May 2020).

The development of the e-commerce industry from year to year seems to be in line with the social media industry, because the two industries benefit one another. One of the roles of social media for e-commerce is to make it easier for users to communicate, either in the form of uploading photos or short videos accompanied by captions in order to reach wider customers. According to the latest Indonesian Internet Service Providers Association (APJII) data survey in 2016, internet users in Indonesia reached 132.7 million and social media Instagram became the second popular social media with a number of users reaching 19.9 million or 15 percent (https://www.kompasiana.com/, downloaded on 20th August 2020).

Of the many existing e-commerce sites, Shopee can prove its identity as a large successful e-commerce. This can be seen from the number of followers and posts on the official Shopee Indonesia account on the social media that Indonesians are most interested in, called Instagram. As the youngest e-commerce among other big competitors in Indonesia, Shopee itself, which was founded in 2015, has 5.1 million followers and 8,641 posts; while Tokopedia, which was founded in 2009, only has 1.9 million followers and 761 posts; Bukalapak, which was founded in 2011, only has 1 million followers and 232 posts; and Lazada, which was founded in 2012, only has 2.1 million followers and 5,649 posts (https://www.instagram.com/, downloaded on 18th May 2020).

Another Shopee success can be seen from its success in serving transactions worth US $\$ 1.8$ billion or around Rp.24 trillion with a growth of around $43 \%$ every month, only after one year of operation since 2015. Shopee is also able to serve more than 250,000 transactions on average every day, with around 100,000 transactions of which originate from Indonesia. Shopee Indonesia which is headquartered at Wisma 77 Tower 211 th floor, J1. Lieutenant General S. Parman Kav. 77 Slipi, Palmerah, West Jakarta, 11410 itself has managed to reach 515 cities and hooked thousands of active users (https://id.techinasia.com/, downloaded on 21st May 2020).

This e-commerce platform based in Singapore has realized that the e-commerce industry has indeed developed far and is increasingly required to meet the needs of the mobile market. Shopee itself has met market needs by continuing to innovate in order to get loyal customers. According to Chris Feng, the Chief Executive of Shopee's Office, one of the keys for customers to be loyal is to always create a feeling of engagement with its users. In this case, Shopee is not only a place to shop online, but Shopee also tries to give its buyers joy when shopping with family and friends. The Shopee logo consists of orange and white colors, of course really reflects the cheerful side which is in line with the company's goal to always bring joy to each of its customers when shopping (https://www.liputan6.com/, downloaded on 21st May 2020).

\section{Literature Review}

\subsection{Theories and Hypotheses}

According to Kim and Ko (2012), social media marketing activities facilitate value creation, increase brand equity, and play a role in fostering customer relationships. The main focus of marketing is to create, communicate and deliver value. Therefore, every marketing activity will seek to increase value equity (Kotler $\&$ Keller, 2016). Ismail (2017) states that the positive relationship between social media marketing activity and value equity has been supported by various empirical studies. Customers regularly visit social media sites and social trading platforms to find out which products can provide optimal value, that is, customers can get the product at the lowest price available without reducing the desired quality and features (Kaplan \& Haenlein, 2010). 
Hypotheses 1: Social Media Marketing Activities has a significant effect on the Value Equity.

Many companies have used social media for marketing and advertising. The use of social media marketing itself has played a role in creating more business opportunities, so that customers can receive brand equity messages and build more significant influential interactions (Kim \& Ko, 2010). This is in accordance with the research of Godey et al. (2016), which states that social media marketing has a significant positive effect on brand equity, because marketing through social media can provide faster and easier information to consumers about the products being sold so that it can provide a positive brand image by increasing brand equity. According to Nam et al. (2011), social media marketing is an online media marketing channel with various updates that are able to improve, boost, and even maintain the stability of the brand equity of a product so that it remains in the midst of intense product competition. According to Ismail (2017), social media marketing makes it easier for customers to interact, communicate, and access images and information from a product, so that it can be better known through brand equity and in the end can have a positive effect. Social media marketing is used to build brand equity by a company, where marketing activities through a social media regulatory system can increase brand equity for consumers (Coulter et al., 2012).

Hypotheses 2: Social Media Marketing Activities has a significant effect on the Brand Equity.

According to Kaplan and Haenlein (2010), social media marketing is of course very close to the role of relationship between every social media user. A similar definition of relationship is also expressed by Tuten and Solomon (2016), who reveal that the basic idea behind the launch of Facebook as an example of social media is its association with "FRIENDS" and building strong relationships. All Facebook activities are built on the foundation of "FRIENDS" which includes relationships. Therefore, social media marketing is relationship-centric. Relationship equity also emphasizes the importance of developing, maintaining and enhancing strong relationships with customers (Kotler \& Keller, 2016). Yadav and Rahman (2017) state that of course the target of relationship equity is to increase customer share and not market share. The positive relationship between social media marketing activites and relationship equity has been confirmed by various empirical studies (Al-alak, 2014).

Hypotheses 3: Social Media Marketing Activities has a significant effect on the Relationship Equity.

Research by Ou et al. (2014) stated that the customer equity driver which includes value equity has a positive relationship with customer loyalty in various service sectors around the world. This is supported by Dwivedi et al. (2012), which states that the positive relationship between value equity and customer loyalty has been supported by various empirical studies. In addition, value equity also affects switching customer propensity, which is a concept similar to customer loyalty (Rust et al., 2004). Value equity becomes vital when there is a difference with competing products that customers can see (Ramaseshan, Rabbanee, \& Hui, 2013). After a company offers superior advantages that are related to perceived cost to customers competitively compared to competitive offerings, this leads to an increase in customers' contentment which in turn leads to repurchase intention so that it has the potential to increase customer loyalty (Zhang et al., 2014).

Hypotheses 4: Value Equity has a significant effect on the Customer Loyalty.

The positive relationship between brand equity and customer loyalty has been supported by various empirical studies (Dwivedi et al., 2012). In research conducted by Razzaq, Yousaf, and Hong (2017), a brand that provides value to the product being sold will provide more value compared to generic products. In addition, if the customer thinks a certain brand can complement his own image, the customer will develop a favorable image of the brand which in turn can increase the likelihood of that brand's preference over competitors. A 
positive opinion from a brand, namely brand equity can positively affect customers' affective commitment, which in turn can have a positive effect on customer loyalty (Ramaseshan, Rabbanee, \& Hui, 2013). Research conducted by Yadav and Rahman (2017) confirms that brand equity is expected to have an impact on readiness to pay, repurchase intention, and the probability of brand's recommendation, where these three things can have a significant indirect effect on customer loyalty.

Hypotheses 5: Brand Equity has a significant effect on the Customer Loyalty.

In the research of Ramaseshan, Rabbanee, and Hui (2013), if the relationship equity perceived by the customer is high, then the customer believes that the customer will be treated well and handled specially. There is a significant relationship between relationship equity, satisfaction, and loyalty (Razzaq, Yousaf, \& Hong, 2017). In addition, research conducted by Yadav and Rahman (2017) also supports a positive relationship between relationship equity and customer loyalty because it has been validated by various empirical studies. The literature of Razzaq et al. (2019) show that there is a strong relationship between relationship equity and customer loyalty.

Hypotheses 6: Relationship Equity has a significant effect on the Customer Loyalty.

\subsection{Research Model}

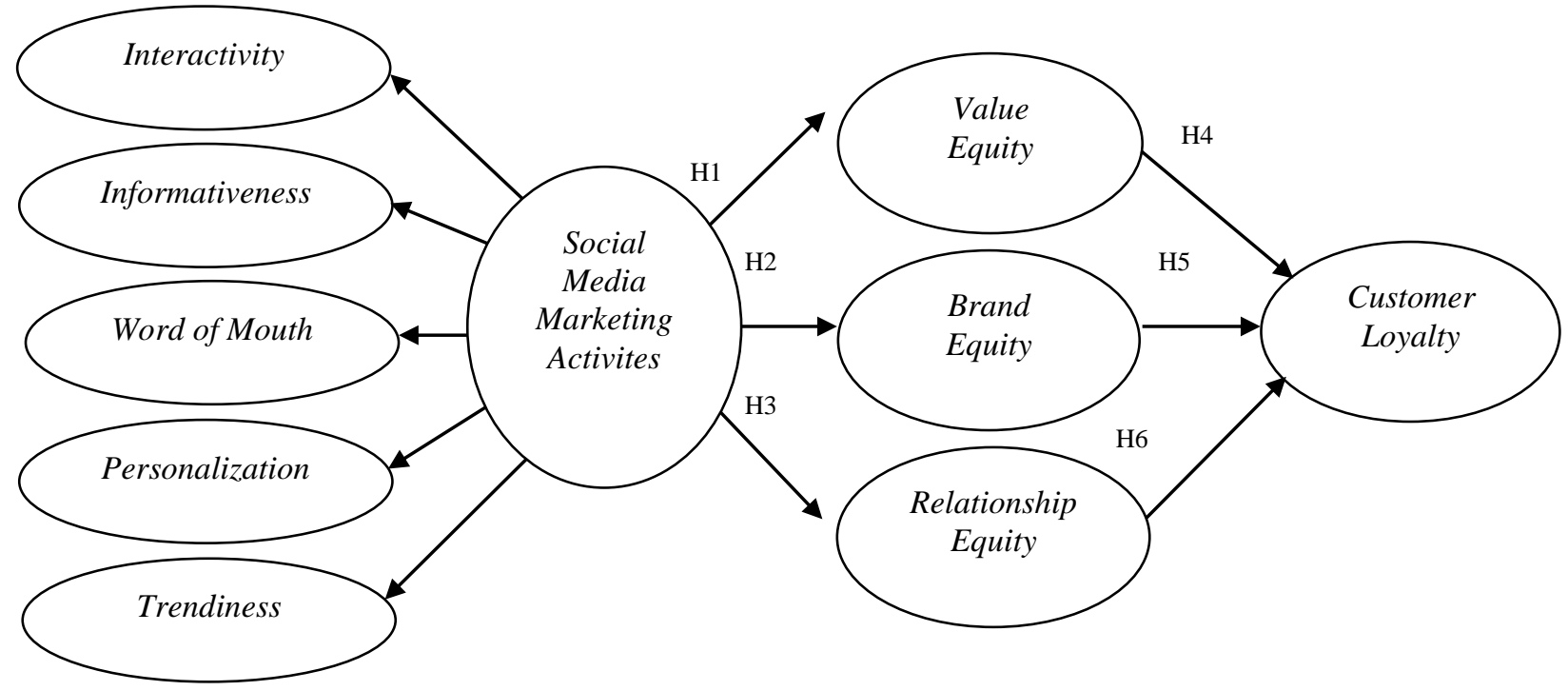

Figure 2.1: The Framework of Research Model

\section{Research Methods}

This research is causal research, because it is used to develop existing research models to test the research hypotheses that are determined based on literature review to answer the problems identified in the previous chapter. The research method used in this study is a quantitative method, where this method is a scientific approach to managerial and economic decision making. The method used in this study will refer to references that can carry out a simultaneous analysis process associated with a multi-variable research model, the Structural Equation Model (SEM). The program used is the AMOS 22.0 software program. This chapter 
describes the object of research directed at analyzing models about the relationship between variables to understand the factors that influence Customer Loyalty from Shopee Indonesia customers on Surabaya.

The sampling method used in this research is non-probability sampling. This study uses a questionnaire as the main tool in data collection. In this study, researchers will use a purposive sampling technique, where researchers determine respondents who will help researchers to distribute and fill out questionnaires. The area used as a place for distributing questionnaires was the Surabaya city, so that respondents were selected according to the criteria determined in this study. The characteristics of the respondents determined are men and women aged 18-60 years where the age is an early adulthood (Kotler and Armstrong, 2010), domiciled in Surabaya, have shopped at Shopee at least twice in the past year, have shopped at other e-commerce sites in the past year, and follow Shopee Indonesia's social media (Instagram) in the last three months.

There are 27 indicators used in this study indicators, from the number of existing indicators, the minimum number of samples used is 100-200 respondents, and for this research the number of respondents is 135 people. Data collection is done by distributing questionnaires to respondents in accordance with the characteristics of the sample that has been described previously. After completing the questionnaire, the respondent returns the questionnaire that has been filled out and will then be selected by the researcher. The selected questionnaire is a questionnaire that is completely filled out and according to the filling instructions. After selection, the selected questionnaire will be further processed. After the data is tabulated, then the research model will be tested using AMOS software version 22.0. The questionnaire in this study will be divided into two parts. The first part contains questions to get general information about the respondent himself that is useful to determine the suitability of the characteristics of the respondents with the sample criteria. The second part contains questions to obtain research data and analyze the effect of Social Media Marketing Activities (SMMA) Dimension, which is Interactivity, Informativeness, Word of Mouth, Personalization, and Trendiness on Customer Loyalty through Value Equity, Brand Equity, and Relationship Equity. The scale used in this study is a Likert Scale, where the answer is provided at intervals from $1=$ Strongly Disagree (STS) to $5=$ Strongly Agree (SS). Statements are made using a scale of 1-5 to obtain internal data.

\section{Results and Discussion}

\subsection{Assessment of Measurement Model}

Table 4.1 Regression Weights Full Structural Equation Model

\begin{tabular}{|l|l|l|r|r|r|r|c|}
\hline & & & Estimate & S.E. & C.R. & P & Std. Estimate \\
\hline Brand_Equity & $<---$ & SMMA &, 067 &, 038 & 1,747 &, 081 &, 267 \\
\hline Value_Equity & $<---$ & SMMA &, 413 &, 069 & 5,969 & $* * *$ &, 980 \\
\hline Relationship_Equity & $<---$ & SMMA &, 784 &, 077 & 10,242 & $* * *$ &, 911 \\
\hline Word_of_Mouth & $<---$ & SMMA &, 827 &, 079 & 10,504 & $* * *$ &, 872 \\
\hline Personalization & $<---$ & SMMA &, 685 &, 072 & 9,560 & $* * *$ &, 922 \\
\hline Trendiness & $<---$ & SMMA &, 267 &, 059 & 4,535 & $* * *$ &, 849 \\
\hline Informativeness & $<---$ & SMMA &, 415 &, 106 & 3,915 & $* * *$ &, 759 \\
\hline Interactivity & $<---$ & SMMA &, 190 &, 045 & 4,181 & $* * *$ &, 756 \\
\hline Customer_Loyalty & $<---$ & Brand_Equity &, 017 &, 179 &, 092 &, 926 &, 010 \\
\hline Customer_Loyalty & $<---$ & Value_Equity &, 806 &, 282 & 2,862 &, 004 &, 798 \\
\hline Customer_Loyalty & $<---$ & Relationship_Equity &, 081 &, 128 &, 629 &, 529 &, 163 \\
\hline X1.3 & $<---$ & Interactivity & 1,754 &, 454 & 3,866 & $* * *$ &, 612 \\
\hline X3.3 & $<---$ & Word_of_Mouth & 1,000 & & & &, 892 \\
\hline
\end{tabular}




\begin{tabular}{|l|r|l|r|r|r|r|r|}
\hline X4.3 & \multicolumn{1}{|c|}{ P--- } & Personalization &, 730 &, 088 & 8,332 & $* * *$ &, 708 \\
\hline X4.2 & $<---$ & Personalization & 1,000 & & & &, 794 \\
\hline Y3.2 & $<---$ & Relationship_Equity &, 597 &, 069 & 8,656 & $* * *$ &, 689 \\
\hline Y1.1 & $<---$ & Value_Equity & 1,000 & & & &, 518 \\
\hline Y1.3 & $<---$ & Value_Equity & 1,622 &, 272 & 5,961 & $* * *$ &, 816 \\
\hline Y1.2 & $<---$ & Value_Equity & 1,167 &, 214 & 5,445 & $* * *$ &, 674 \\
\hline Y2.1 & $<---$ & Brand_Equity & 2,269 &, 992 & 2,287 &, 022 &, 511 \\
\hline Y2.2 & $<---$ & Brand_Equity & 1,000 & & & &, 443 \\
\hline Y2.3 & $<---$ & Brand_Equity & 1,028 &, 462 & 2,225 &, 026 &, 470 \\
\hline Y3.1 & $<---$ & Relationship_Equity &, 891 &, 085 & 10,427 & $* * *$ &, 798 \\
\hline Y3.3 & $<---$ & Relationship_Equity & 1,000 & & & &, 843 \\
\hline Y4.1 & $<---$ & Customer_Loyalty & 1,000 & & & &, 652 \\
\hline Y4.2 & $<---$ & Customer_Loyalty & 1,542 &, 212 & 7,269 & $* * *$ &, 766 \\
\hline Y4.3 & $<---$ & Customer_Loyalty &, 850 &, 171 & 4,971 & $* * *$ &, 475 \\
\hline X1.1 & $<---$ & Interactivity & 1,000 & & & &, 457 \\
\hline X1.2 & $<---$ & Interactivity & 1,104 &, 330 & 3,341 & $* * *$ &, 469 \\
\hline X2.3 & $<---$ & Informativeness & 1,018 &, 246 & 4,145 & $* * *$ &, 759 \\
\hline X2.2 & $<---$ & Informativeness & 1,000 & & & &, 410 \\
\hline X2.1 & $<---$ & Informativeness & 1,296 &, 309 & 4,191 & $* * *$ &, 816 \\
\hline X3.1 & $<---$ & Word_of_Mouth &, 975 &, 083 & 11,789 & $* * *$ &, 815 \\
\hline X3.2 & $<---$ & Word_of_Mouth &, 811 &, 079 & 10,230 & $* * *$ &, 747 \\
\hline X4.1 & $<---$ & Personalization &, 789 &, 098 & 8,046 & $* * *$ &, 694 \\
\hline X5.2 & $<---$ & Trendiness & 2,728 &, 591 & 4,614 & $* * *$ &, 848 \\
\hline X5.3 & $<---$ & Trendiness & 1,310 &, 315 & 4,162 & $* * *$ &, 547 \\
\hline X5.1 & $<---$ & Trendiness & 1,000 & & & &, 437 \\
\hline S5ur & & & \\
\hline
\end{tabular}

Source: Text Output AMOS 22.0 (2020)

C.R. value for each relationship between the variables tested are shown in table 4.1. Causality relationship that occurs between variables Social Media Marketing Activities (SMMA) to Value Equity, Social Media Marketing Activities (SMMA) to Relationship Equity, and Value Equity to Customer Loyalty have a significant relationship because the C.R value is above 2.00. As for the causality relationship that occurs between the Social Media Marketing Activities (SMMA) to Brand Equity, Brand Equity to Customer Loyalty, and Relationship Equity to Customer Loyalty has insignificant relationship because the value of C.R is below 2.00.

\subsection{Hypotheses Testing}

Table 4.2 Summary of Testing Results

\begin{tabular}{|l|l|}
\hline \multicolumn{1}{|c|}{ Hypotheses } & \multicolumn{1}{c|}{ Analysis } \\
\hline $\mathrm{H}_{1}:$ Social Media Marketing Activities (SMMA) significantly affected to Value Equity & Accepted \\
\hline $\mathrm{H}_{2}:$ Social Media Marketing Activities (SMMA) significantly affected to Brand Equity & Not Accepted \\
\hline $\begin{array}{l}\text { H3 : Social Media Marketing Activities (SMMA) significantly affected to Relationship } \\
\text { Equity }\end{array}$ & Accepted \\
\hline $\mathrm{H}_{4}:$ Value Equity significantly affected to Customer Loyalty & Accepted \\
\hline $\mathrm{H}_{5}:$ Brand Equity significantly affected to Customer Loyalty & Not Accepted \\
\hline $\mathrm{H}_{6}:$ Relationship Equity significantly affected to Customer Loyalty & Not Accepted \\
\hline
\end{tabular}

Source: Amos 22.0 Analysis Result, 2020 


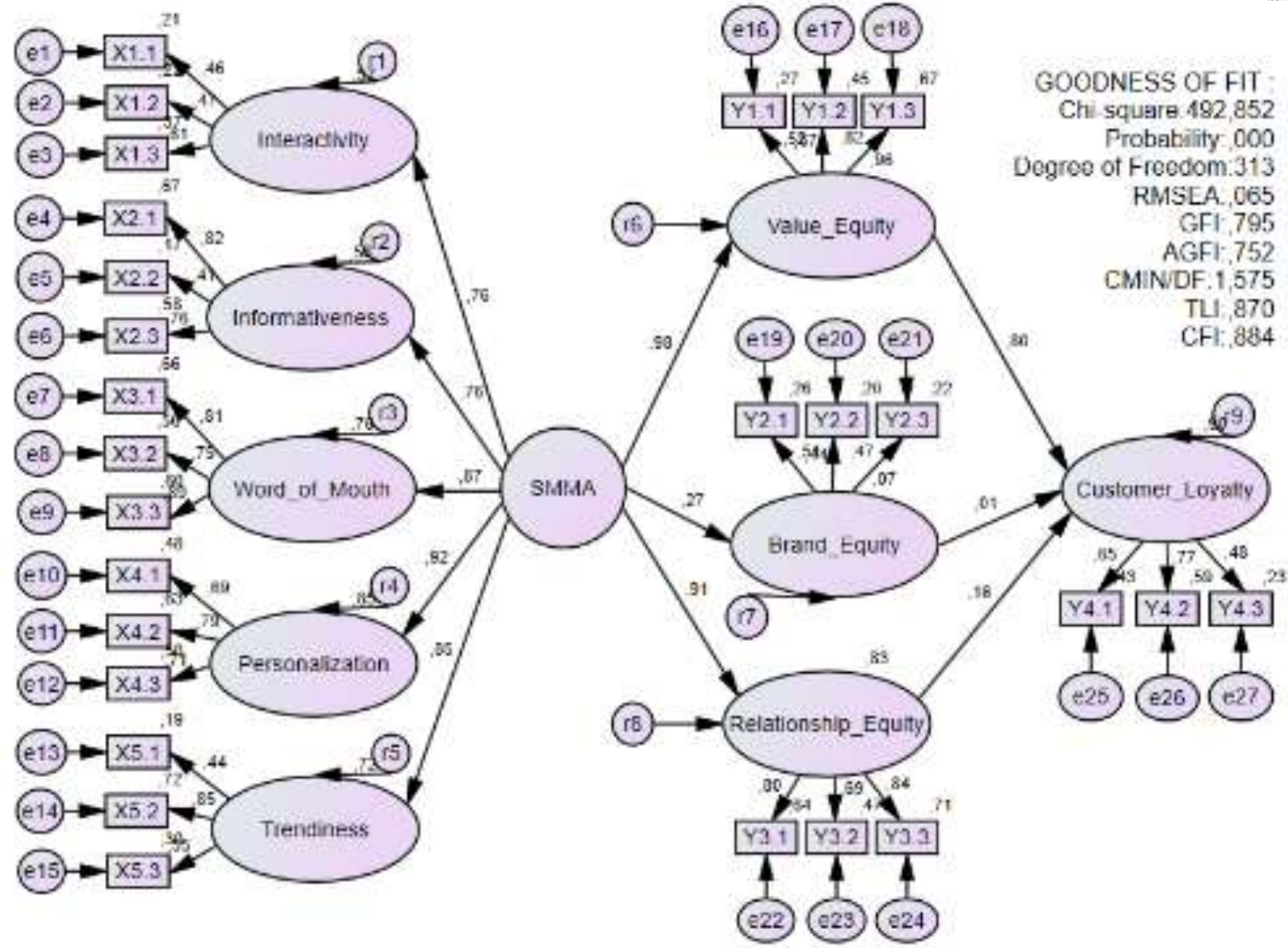

Figure 4.1 The Framework of Analysis Result

Source: Amos 22.0 Analysis Result, 2020

\subsection{Discussion}

Based on Amos 22.0 analysis result, estimation parameters between Social Media Marketing Activities (SMMA) to Value Equity, Social Media Marketing Activities (SMMA) to Relationship Equity, and Value Equity to Customer Loyalty has a significant results in a positive direction with a value of C.R $\geq \pm 2.00$ with a significance level $<0.05$ (5\%), so it can be said that hypothesis H1, H3, and H4 was accepted (This were showed at Table 4.1 and Table 4.2). As for the estimation parameters between the Social Media Marketing Activities (SMMA) to Brand Equity, Brand Equity to Customer Loyalty, and Relationship Equity to Customer Loyalty has insignificant relationship because the value of C.R is below 2.00, so it can be said that hypothesis H2, H5, and H6 was not accepted (This were showed at Table 4.1 and Table 4.2). The findings of this study provide several important implications for Customer Loyalty research and practice, especially in e-commerce industry in the future.

The estimation parameters between Social Media Marketing Activities (SMMA) and Value Equity show significant results in a positive direction with a value of C.R $=5,969$ and a regression coefficient of 0,980 , with an acceptable hypothesis standard that is C.R. $\geq \pm 2.00$ and significance level $<0.05(5 \%)$, it can be said that hypothesis 1 (H1) is accepted. Social media marketing activities are formed by second order interactivity, informativeness, word of mouth, personalization, and trendiness. Whereas value equity is formed by the 
indicator of product prices displayed on Shopee Indonesia's social media (Instagram) according to their quality, It's easier than ever to buy Shopee products because of the completeness of the information displayed on Shopee Indonesia's social media (Instagram), and information displayed in the media social (Instagram) Shopee allows you to get product information at any time, making it easier to shop on the Shopee application.

The estimation parameters between Social Media Marketing Activities (SMMA) and Brand Equity show insignificant positive results with a value of C.R $=1,747$ and a regression coefficient of 0,267 , with an acceptable hypothesis standard that is C.R. $\geq \pm 2.00$ and and significance level $<0.05(5 \%)$, it can be said that hypothesis $2(\mathrm{H} 2)$ is rejected. Social media marketing activities are formed by second order interaction, informativeness, word of mouth, personalization, and trendiness. While brand equity is formed by the social media indicator (Instagram) Shopee Indonesia is able to explain the existence of the Shopee brand as the best online shopping platform, Shopee Indonesia's social media (Instagram) is able to explain the existence of the Shopee brand as an innovative brand, and social media (Instagram) Shopee Indonesia able to explain the existence of the Shopee brand as a well-known brand.

The estimation parameters between Social Media Marketing Activities (SMMA) and Relationship Equity Identification show significant results in a positive direction with a value of C.R $=10,242$ and a regression coefficient of 0,911, with an acceptable hypothesis standard that is C.R. $\geq \pm 2.00$ and significance level $<0.05$ $(5 \%)$, it can be said that hypothesis $3(\mathrm{H} 3)$ is accepted. Social media marketing activities are formed by second order interaction, informativeness, word of mouth, personalization, and trendiness. Meanwhile, relationship equity is formed by the indicator of feeling a good emotional attachment to Shopee Indonesia's social media (Instagram), feeling comfortable with Shopee Indonesia's social media (Instagram), and feeling committed to Shopee Indonesia's social media (Instagram).

The estimation parameters between Value Equity and Customer Loyalty showed significant results in a positive direction with a value of C.R $=2,862$ and a regression coefficient of 0,798 , with an acceptable hypothesis standard that is C.R. $\geq \pm 2.00$ and significance level $<0.05(5 \%)$, it can be said that hypothesis 4 (H4) is accepted. Value equity is formed by the indicator of product prices displayed on Shopee Indonesia's social media (Instagram) according to their quality, it is easier to buy Shopee products thanks to the completeness of information displayed on Shopee Indonesia's social media (Instagram), and information displayed on social media. (Instagram) Shopee allows you to get product information at any time, making it easier to shop on the Shopee application. Meanwhile, customer loyalty is formed by an indicator that will make a repurchase at Shopee from the content offered on Shopee Indonesia's social media (Instagram), will recommend Shopee Indonesia's social media (Instagram) to my friends, and will return to Shopee Indonesia's social media (Instagram).

The estimation parameters between Brand Equity and Customer Loyalty showed insignificant results in a positive direction with a value of C.R $=0,092$ and a regression coefficient of 0,010 , with an acceptable hypothesis standard that is C.R. $\geq \pm 2.00$ and significance level $<0.05(5 \%)$, it can be said that hypothesis 5 (H5) is rejected. Brand equity is formed by the social media indicator (Instagram) Shopee Indonesia is able to explain the existence of the Shopee brand as the best online shopping platform, social media (Instagram) Shopee Indonesia is able to explain the existence of the Shopee brand as an innovative brand, and social media (Instagram) Shopee Indonesia is able to explained the existence of the Shopee brand as a well-known brand. Meanwhile, customer loyalty is formed by an indicator that will make a repurchase at Shopee from the content offered on Shopee Indonesia's social media (Instagram), will recommend Shopee Indonesia's social media (Instagram) to my friends, and will return to Shopee Indonesia's social media (Instagram).

The estimation parameters between Relationship Equity and Customer Loyalty showed insignificant results in a positive direction with a value of C.R $=0,629$ and a regression coefficient of 0,163 , with an acceptable 
hypothesis standard that is C.R. $\geq \pm 2.00$ and significance level $<0.05(5 \%)$, it can be said that hypothesis 6 (H6) is rejected. Relationship equity is formed by indicators of feeling a good emotional attachment to Shopee Indonesia's social media (Instagram), feeling comfortable with Shopee Indonesia's social media (Instagram), and feeling committed to Shopee Indonesia's social media (Instagram). Meanwhile, customer loyalty is formed by an indicator that will make a repurchase at Shopee from the content offered on Shopee Indonesia's social media (Instagram), will recommend Shopee Indonesia's social media (Instagram) to my friends, and will return to Shopee Indonesia's social media (Instagram).

\section{Conclusion}

This study provides evidence that the Social Media Marketing Activities (SMMA) significantly affected Value Equity, Social Media Marketing Activities (SMMA) insignificantly affected Brand Equity, Social Media Marketing Activities (SMMA) significantly affected Relationship Equity, Value Equity significantly affected Customer Loyalty, Brand Equity insignificantly affected Customer Loyalty, and Relationship Equity insignificantly affected Customer Loyalty.

\subsection{Managerial Implications}

Table 5.1 Managerial Implications

\begin{tabular}{|c|c|}
\hline Current Research & Managerial Implications \\
\hline $\begin{array}{l}\text { Personalization is a facility that } \\
\text { is given from a e-commerce to } \\
\text { customers through e-commerce } \\
\text { social media, is related to the } \\
\text { strategy of offering content that } \\
\text { can be tailored to customer } \\
\text { preferences / needs (Martin and } \\
\text { Todorov, 2010). }\end{array}$ & $\begin{array}{l}\text { X4.2 Socialize the schedule for uploading content about various } \\
\text { products to Shopee's social media (Instagram) Indonesia. } \\
\text { X4.3 Any content that has been uploaded to the feed should be uploaded } \\
\text { to Instagram Story so that the content can be highlighted and then } \\
\text { given a clear name. } \\
\text { X4.1 Organize a short survey using the help of the poll feature or the } \\
\text { questions feature on Instagram Story about what items Shopee } \\
\text { rarely displays on Shopee Indonesia's social media (Instagram). }\end{array}$ \\
\hline $\begin{array}{l}\text { Word of mouth is informal } \\
\text { communication carried out by a } \\
\text { person or group of people to } \\
\text { other people, with the focus of } \\
\text { communication on providing } \\
\text { information about the experience } \\
\text { of using a product / service, its } \\
\text { features, and even all information } \\
\text { related to the seller (Berger, } \\
2014 \text { ). }\end{array}$ & $\begin{array}{l}\text { X3.3 Create a giveaway in a more attractive form (customers are required } \\
\text { to share their purchasing experience when shopping at the } \\
\text { e-commerce Shopee). } \\
\text { X3.1 Providing a referral code feature on Shopee's e-commerce, which } \\
\text { can only be obtained when customers are Shopee Indonesia's social } \\
\text { media (Instagram) followers. } \\
\text { X3.2 Create mini games on Instagram Story with the help of templates. } \\
\text { Example: Bingo games. }\end{array}$ \\
\hline $\begin{array}{l}\text { Trendiness is a facility that is } \\
\text { given from a e-commerce to } \\
\text { customers through e-commerce } \\
\text { social media, related to trendy } \\
\text { content, the latest information, } \\
\text { and trending news (Naaman et } \\
\text { al., (2011). }\end{array}$ & $\begin{array}{l}\text { X5.2 Provides everything trendy quickly according to the right timing } \\
\text { when the trend is taking place. } \\
\text { X5.3 Do Instagram live more often, namely } 2 \mathrm{x} \text { a week. } \\
\text { X5.1 Schedule content uploads every Saturday, which is about the } \\
\text { content "Did You Know". }\end{array}$ \\
\hline
\end{tabular}


Informativeness is a given facility of a e-commerce to customers through e-commerce social media, related to various kinds of information that are accurate, useful, and also complete (Kim et al., 2010).

Interactivity is a facility given from a e-commerce to customers through e-commerce social media, so that customers can share content and views with companies and other customers (Gallaugher and Ransbotham, 2010).

Value equity is an objective assessment of the customer for the usefulness of a brand, based on the perception of what a brand has given to what the customer feels (Zhang et al., 2016).

X2.1 When uploading a product being sold, Shopee Indonesia's social media (Instagram) must always display a link that is linked to the Shopee e-commerce product page.

X2.3 Organize Instagram Story highlights with well categorizes.

$\mathrm{X} 2.2$ Make the content clearer and more assertive, that is always provide information about who is the target of the content in the captions / feeds.

X1.3 Create the competition more interesting, such as group competitions called the Shopee Haul Group video (reviewing various items as a group).

X1.2 Upload about various kinds of phenomena that can make Indonesian people more integrated.

X1.1 Doing activities that can lead to two-way communication (utilizing Instagram Story features such as polls, quizzes, and questions).

Y1.3 Always display information on Shopee Indonesia's social media (Instagram) quickly.

Y1.2 Synchronizing Instagram and Shopee, so that when there are feeds containing product advertisements, customers can buy them directly from the Shopee e-commerce application (not only through the website).

Y1.1 Always provide a free program with a maximum postage of IDR 10,000 with a minimum spend of IDR 0 per month.

Relationship equity is the tendency of customers to stay in touch with a brand, beyond an objective and subjective assessment of the brand (Zhang et al., 2016).
Y3.3 Always active (online) and always doing activities on Instagram, such as uploading Instagram stories and feeds every day.

Y3.2 Back to using the feeds template with Shopee's signature orange background.

Y3.1 Always reply to every direct message and comment that comes in using non-formal language that is slang but still polite, and uses jargon as a greeting sentence to customers.

Y2.1 Implementing business branding on an Instagram account by providing highlights or IGTV entitled "Why Us".

Y2.3 Provides material about the expansion of Shopee in any country. In addition, the provision of material can also contain the development of the number of users and official sellers every year.

Y2.2 Providing material on how to use and benefit from various features that available in Shopee e-commerce, such as various game features, ShopeePay Deals Rp1 feature, and other features.

\subsection{Recommendation}

Since the results of existing research conducted by this writer still have many limitations, so the recommendations that can be submitted by the author for further research are : 
8.1. There are limitations in this study regarding the object of research that only takes respondents namely Shopee Indonesia's social media (Instagram) customers in Surabaya, then in the next study it is expected to use the same or modified model, then it can be applied to different objects to get more general results to the factors that affect Customer Loyalty.

8.2. Further research is expected to complement the existing variables in this research, so that it can further enhance the understanding of the factors that affect Customer Loyalty, such as trust, advertisement, product quality, service quality, customer satisfaction, product attribute, perceived switching cost, attractiveness of alternatives, or other variables.

8.3. Further research can be developed by linking the factors that affect Customer Loyalty based on income level and education level. Future research can also expand the scope of respondents who will be researched, or carry out their research in a different area from the current research (other than Surabaya), so that further research can provide a broader picture of Customer Loyalty.

8.4. In addition, it is also expected to be able to use the Structural Equational Model (SEM) but by using Lisrel software for further research.

\section{References}

Al-alak, B. A. (2014). Impact of marketing activities on relationship quality in the Malaysian banking sector. Journal of Retailing and Consumer Services, 21(3), 347-356.

Anonimus. (2020, 17 Mei). Sejarah e-commerce Indonesia: Apa yang telah dan akan terjadi? Kompasiana. Diunduh dari https://www.kompasiana.com/www.bhinneka.com/59b25877085ea65943594dc2/sejarah-e-commerce-indonesia-apa-yangtelah-dan-akan-terjadi?page $=4$

Anonimus. (2020, 20 Agustus). Peran Media Sosial Instagram dalam Penyebaran Berita. Diunduh dari https://www.kompasiana.com/bencha/59d0da972ba8d16a6211c7f2/peran-media-sosial-instagram-dalam-penyebaran-berita

Berger, J. (2014). Word of mouth and interpersonal communication: A review and directions for future research. Journal of consumer psychology, 24(4), 586-607.

Coulter, K. S., Bruhn, M., Schoenmueller, V., \& Schäfer, D. B. (2012). Are social media replacing traditional media in terms of brand equity creation? Management research review.

Dwivedi, A., Merrilees, B., Miller, D., \& Herington, C. (2012). Brand, value and relationship equities and loyalty-intentions in the Australian supermarket industry. Journal of Retailing and Consumer Services, 19(5), 526-536.

Gallaugher, J., \& Ransbotham, S. (2010). Social media and customer dialogue management at Starbucks. MIS Quarterly Executive, 9(4), 197-212.

Godey, B., Manthiou, A., Pederzoli, D., Rokka, J., Aiello, G., Donvito, R., \& Singh, R. (2016). Social media marketing efforts of luxury brands: Influence on brand equity and consumer behavior. Journal of business research, 69(12), 5833-5841.

Ismail, A. R. (2017). The influence of perceived social media marketing activities on brand loyalty: The mediation effect of brand and value consciousness. Asia Pacific Journal of Marketing and Logistics, 29(1), 129-144.

Kaplan, A. M., \& Haenlein, M. (2010). Users of the world, unite! The challenges and opportunities of Social Media. Business horizons, 53(1), 59-68.

Kim, A. J., \& Ko, E. (2010). Impacts of luxury fashion brand's social media marketing on customer relationship and purchase intention. Journal of Global Fashion Marketing, 1(3), 164-171.

Kim, J. U., Kim, W. J., \& Park, S. C. (2010). Consumer perceptions on web advertisements and motivation factors to purchase in the online shopping. Computers in human behavior, 26(5), 1208-1222.

Kotler, P., \& Armstrong, G. (2010). Principles of marketing. Pearson education.

Kotler, P., \& Keller, K. L. (2016). Marketing Management (15 ed). Noida: Pearson

Martin, K., \& Todorov, I. (2010). How will digital platforms be harnessed in 2010, and how will they change the way people interact with brands?. Journal of Interactive Advertising, 10(2), 61-66.

Naaman, M., Becker, H., \& Gravano, L. (2011). Hip and trendy: Characterizing emerging trends on Twitter. Journal of the American Society for Information Science and Technology, 62(5), 902-918.

Nam, J., Ekinci, Y., \& Whyatt, G. (2011). Brand equity, brand loyalty and consumer satisfaction. Annals of tourism Research, 38(3), 1009-1030.

Nurdiarsih, F. (2020, 21 Mei). Shopee catatkan 1,2 juta transaksi per hari di Indonesia. Diunduh dari https://www.liputan6.com/bisnis/read/4088547/shopee-catatkan-12-juta-transaksi-per-hari-di-indonesia

Ou, Y. C., de Vries, L., Wiesel, T., \& Verhoef, P. C. (2014). The role of consumer confidence in creating customer loyalty. Journal of Service Research, 17(3), 339-354. 
Pratama, A. H. (2020, 21 Mei). Bagaimana kiprah Shopee selama setahun di dunia marketplace Tanah Air? Diunduh dari https://id.techinasia.com/perjalanan-shopee-setelah-1-tahun-beroperasi-di-indonesia

Ramaseshan, B., Rabbanee, F. K., \& Hui, L. T. H. (2013). Effects of customer equity drivers on customer loyalty in B2B context. Journal of Business \& Industrial Marketing.

Razzaq, Z., Razzaq, A., Yousaf, S., Akram, U., \& Hong, Z. (2019). The impact of customer equity drivers on loyalty intentions among Chinese banking customers. Asia Pacific Journal of Marketing and Logistics.

Razzaq, Z., Yousaf, S., \& Hong, Z. (2017). The moderating impact of emotions on customer equity drivers and loyalty intentions. Asia Pacific Journal of Marketing and Logistics.

Tuten, T. L., \& Solomon, M. R. (2016). Social Media Marketing (2 ed.). New Delhi, India: Sage Texts.

Yadav, M., \& Rahman, Z. (2017). Social media marketing: literature review and future research directions. International Journal of Business Information Systems, 25(2), 213-240.

Zhang, K. Z., Benyoucef, M., \& Zhao, S. J. (2016). Building brand loyalty in social commerce: The case of brand microblogs. Electronic Commerce Research and Applications, 15, 14-25.

Zhang, S. S., van Doorn, J., \& Leeflang, P. S. (2014). Does the importance of value, brand and relationship equity for customer loyalty differ between Eastern and Western cultures? International business review, 23(1), 284-292.

\section{Appendix}

Table 6 Questionnaire

\section{Interactivity}

X1.1: I feel that Shopee Indonesia is able to well interact with its customers through existing social media (Instagram)

X1.2: I feel that Shopee Indonesia through its social media (Instagram), is able to display positive interactions with all of its customers

X1.3: I feel that Shopee Indonesia's social media (Instagram) provides an opportunity to interact with other Shopee customers well

\section{Informativeness}

X2.1: I feel that Shopee Indonesia's social media (Instagram) provides accurate information about every product

X2.2: I feel Shopee Indonesia's social media (Instagram) provides useful information

X2.3: I feel that Shopee Indonesia's social media (Instagram) provides complete information

\section{Word of Mouth}

X3.1: I got a recommendation from my friend to visit Shopee Indonesia's social media (Instagram)

X3.2: I received positive stories about Shopee Indonesia's social media (Instagram) from my friends

X3.3: I became a target for my friends to share their Shopee purchase experience on Shopee Indonesia's social media (Instagram)

\section{Personalization}

X4.1: Shopee Indonesia's social media (Instagram) provided purchase recommendations according to my needs

X4.2: I feel that my needs are met when I use Shopee Indonesia's social media (Instagram)

X4.3: Shopee Indonesia's social media (Instagram) facilitates the search for information that suits my needs

\section{Trendiness}

X5.1: Shopee Indonesia's social media (Instagram) contains content about the latest trends

X5.2: I feel trendy when I use Shopee Indonesia's social media (Instagram)

X5.3: Everything trendy is available on Shopee Indonesia's social media (Instagram)

\section{Value Equity}


Y1.1: The prices of products displayed on Shopee Indonesia's social media (Instagram) match their quality

Y1.2: It is easier for me to buy Shopee products because of the completeness of information displayed on Shopee Indonesia's social media (Instagram)

Y1.3: The information displayed on Shopee's social media (Instagram) allows me to get product information at any time, making it easier for me to shop on the Shopee application

\section{Brand Equity}

Y2.1: Shopee Indonesia's social media (Instagram) is able to explain the existence of the Shopee brand as the best online shopping platform

Y2.2: Social media (Instagram) Shopee Indonesia is able to explain the existence of the Shopee brand as an innovative brand

Y2.3: Shopee Indonesia's social media (Instagram) is able to explain the existence of the Shopee brand as a well-known brand

\section{Relationship Equity}

Y3.1: I feel I have a good emotional attachment to Shopee Indonesia's social media (Instagram)

Y3.2: I feel comfortable with Shopee Indonesia's social media (Instagram)

Y3.3: I feel committed to social media (Instagram) Shopee Indonesia

\section{Customer Loyalty}

Y4.1: I will make a repurchase on Shopee of the content offered on Shopee Indonesia's social media (Instagram)

Y4.2: I will recommend Shopee Indonesia's social media (Instagram) to my friends

Y4.3: I will return to Shopee Indonesia's social media (Instagram) 